\title{
PELATIHAN KETRAMPILAN BERCOCOK TANAM MENGGUNAKAN HIDROPONIK BAGI PENSIUNAN PNS DI KELURAHAN GAYUNGAN
}

\author{
Oleh: \\ : Diastian Vinaya Wijanarko ${ }^{1}$, Akhmad Hafizh Ainur Rasyid ${ }^{2}$, Mochamad Arif Irfa'i ${ }^{3}$, Bellina \\ Yunitasari ${ }^{4}$ \\ 1,2,3,4 Universitas Negeri Surabaya \\ 1diastianwijanarko@unesa.ac.id \\ 2akhmadrasyid@unesa.ac.id \\ 3arifirfai@unesa.ac.id \\ 4bellinayunitasari@unesa.ac.id
}

\begin{abstract}
Abstrak
Pertanian merupakan usaha yang cukup menjanjikan di Indonesia, salah satu bentuk produksinya adalah sayuran. Sayuran merupakan makanan pendamping makanan pokok yang kaya gizi. Didalam sayuran terkandung protein, vitamin dan mineral. Sayuran dalam bidang hortikultura dapat diartikan bagian dari tunas, daun, buah dan akar tanaman yang lunak dan dapat dimakan secara utuh atau sebagian dalam keadaan segar atau mentah atau dimasak, sebagai pelengkap pada makanan berpati dan daging. mencapai 176.000 ton dengan nilai 171,5 juta rupiah (Direktorat jenderal hortikultura, 2009). Dengan semakin sadarnya masyarakat akan kebutuhan akan gizi didalam sayuran, maka permintaan sayuran akan semakin banyak. Hal ini menyebabkan kebutuhan lahan pertanian yang semakin besar. Untuk memenuhi kebutuhan tersebut khususnya bagi masyarakat perkotaan akan mengalami kesulitan terkait dengan jumlah lahan. Alternatif untuk mengatasi permasalahan tersebut adalah dengan menggunakan Hidroponik. Mitra dalam kegiatan Pengabdian kepada Masyarakat (PkM) ini adalah pensiunan PNS yang beralamatkan di Kecamatan Gayungan RT 4/ RW 6 Kelurahan Gayungan Surabaya berjumlah 20 orang yang memiliki latar belakang pendidikan dari SMA sampai Perguruan Tinggi. Hasil yang diperoleh dari kegiatan PkM ini adalah warga pensiunan PNS di Kecamatan Gayungsari adalah modul dan peserta dapat menanam dengan menggunakan media hidroponik.
\end{abstract}

Kata Kunci: bercocok tanam, pensiunan CPNS, sayuran

\section{Abstract}

Agriculture is a promising business in Indonesia, one form of production is vegetables. Vegetables are complementary foods that are rich in nutrients. Vegetables contain protein, vitamins, and minerals. Vegetables in the field of horticulture can be defined as part of the soft shoots, leaves, fruit, and roots of plants and can be eaten whole or partly fresh or raw or cooked, as a complement to starchy foods and meat. reached 176,000 tons with a value of 171.5 million rupiahs (Directorate General of Horticulture, 2009). As people become more aware of the need for nutrition in vegetables, the demand for vegetables will increase. This results in a greater need for agricultural land. To meet these needs, especially urban communities will experience difficulties related to the amount of land. An alternative to solve this problem is to use hydroponics. Partners in this Community Service (PkM) activity are retired civil servants whose address is in Gayungan District RT 4 / RW 6, Gayungan Surabaya Village, totaling 20 people who have educational backgrounds from high school to university. The results obtained from this PkM activity are that retired civil servants in Gayungsari District are modules and participants can plant using hydroponic media.

Keywords: farming, retired civil servants, vegetables

\section{PENDAHULUAN}

Pertanian merupakan usaha yang cukup menjanjikan di Indonesia, salah satubentuk produksinya adalah sayuran. Sayuran merupakan makanan pendamping makanan pokok yang kaya gizi. Didalam sayuran terkandung protein, vitamin dan mineral.
Sayuran dalam bidang hortikultura dapat diartikan bagian dari tunas, daun, buah dan akar tanaman yang lunak dan dapat dimakan secara utuh atau sebagian dalam keadaan segar atau mentah atau dimasak, sebagai pelengkap pada makanan berpati dan daging. Secara nasional, produksi sayuran tahun 2003 sebesar 8,6 juta ton meningkat menjadi 9,6 juta ton pada tahun 2008, yang juga 
diikuti oleh peningkatan jumlah tenaga kerja pada level usaha tani dari 2,3 juta orang pada tahun 2003 menjadi 3,0 juta orang pada tahun 2006. Volume ekspor sayuran pada tahun 2008 mencapai 176.000 ton dengan nilai 171,5 juta US\$ (Direktorat jenderal hortikultura, 2009). Dengan semakin sadarnya masyarakat akan kebutuhan akan gizi didalam sayuran, maka permintaan sayuran akan semakin banyak. Hal ini menyebabkan kebutuhan lahan pertanian yang semakin besar. Untuk memenuhi kebutuhan tersebut khususnya bagi masyarakat perkotaan akan mengalami kesulitan terkait dengan jumlah lahan. Alternatif untuk mengatasi permasalahan tersebut adalah dengan menggunakan Hidroponik.

Hidroponik merupakan sebuah sistem bercocok tanam tanpa menggunakan media tanah. Kelebihan dari sistem hidroponik ini adalah selain dapat mengatasi penggunaan lahan yang terbatas, sistem juga bisa tumbuh di mana saja dan tak tergantung pada musim. Bahkan di wilayah pesisir dengan iklim panas dapat menumbuhkan tanaman dengan dengan baik.

Mitra dalam kegiatan PkM ini adalah pensiunan PNS yang beralamatkan di Kecamatan Gayungan RT 4/ RW 6 Kelurahan Gayungan Surabaya berjumlah 25 orang yang memiliki latar belakang pendidikan dari SMA sampai Perguruan Tinggi. Perkumpulan ini memiliki permasalahan yaitu mereka yaitu setelah mencapai usia pensiun, mereka mengalami kejenuhan akibat berkurangnya aktivitas berkarya. Oleh karena itu, dibutuhkan sebuah kegitana alternatif untuk memberikan aktivitas baru yang bermanfaat untuk menambah pengetahuan, tempat untuk berkarya, serta menambah pendapatan baru sehingga dapat memberikan manfaat bagi mitra kegiatan PkM.

Berdasarkan peluang yang ada, UNESA sebagai salah satu Universitas yang telah dilengkapi dengan pengetahuan akan teknologi dirasa mampu memberikan pelatihan ketrampilan bercocok tanam pada Perkumpulan Pensiunan PNS di kecamatan Gayungan sebagai bentuk pengabdian kepada masyarakat.

\section{METODE}

Metode pendekatan dalam PkM ini menggunakan pendidikan masyarakat yang mengacu pada kebutuhan akan bercocok tanam dengan menggunakan media hidroponik sebagai upaya mendongkrak pendapatan warga kelurahan Gayungan Surabaya di RT 4/ RW 6 selaku mitra ditawarkan kegiatan pelatihan keahlian bercocok tanam dengan menggunakan media hidroponik dengan:

a. Merumuskan masalah

Kebutuhan tambahan kegiatan bagi pensiunan PNS di Kecamatan Gayungan Surabaya sangat dibutuhkan saat ini. Warga Pensiunan PNS di kelurahan Gayungan di RT 4/ RW 6 Surabaya merupakan warga dengan potensi yang dapat dikaryakan. Bagaimana memberikan keterampilan bercocok tanam dengan menggunakan media hidroponik.

b. Metode kegiatan

Metode kegiatan yang akan dilakukan adalah pendidikan masyarakat dengan menggunakan gabungan model pembelajaran ruang kelas dan praktek diharapkan pelatihan bisa berjalan efektif. Pembelajaran ruang kelas digunakan untuk menyampaikan teori-teori dan berbagai metode pada penanaman. Pembelajaran simulasi digunakan pada saat praktek penanaman dengan menggunakan hidroponik dimana nantinya setiap peserta akan diberikan media dan alat secara langsung untuk berlatih.

Pelaksanaan kegiatan PKM diselenggrakan di Kantor Desa Kelurahan Gayungan RT 4/ RW 6 kecamatan Gayungan Surabaya dengan tahapan sebagai berikut:

a. Koordinasi Kegiatan

Koordinasi kegiatan melibatkan warga Gayungan selaku mitra bekerjasama dengan Jurusan Teknik Mesin FT Unesa. Pada tahap ini dilakukan penyampaian kegiatan beserta tujuan yang ingin dicapai.

b. Persiapan peralatan pelatihan

Persiapan peralatan dilakukan seluruhnya oleh tim pengusul kegiatan. Pada tahap ini juga dilakukan penyampaian materi yang disusun dalam betuk modul. Materi berisi teori-teori, kegiatan praktek dan form penilaian.

c. Penjaringan peserta yang nantinya akan didata dan diklasifikasikan berdasarkan umur dan kemampuan

d. Pelaksanaan pelatihan yang dipandu oleh Tutor ahli dari tim jurusan Teknik Mesin FT Unesa. Pelatihan terdiri dari 2 tahapan kegiatan, yaitu :

Minggu ke-1 : Teori Peralatan Hidroponik

Minggu ke-2: Teori Bahan-bahan media tanam hidroponik 
Minggu ke-3 : Praktek

Minggu ke-4 : Praktek

e. Evaluasi hasil.

Peserta mampu memahami proses penanaman hidroponik baik secara teori maupun praktek. Evaluasi kegiatan pelatihan didasarkan pada beberapa indikator secara langsung antara lain: pelaksanaan pelatihan lancar, antusias dari sasaran yang ditunjukkan dengan jumlah kehadiran dan banyaknya pertanyaan, serta semangat dalam mengikuti pelatihan, juga bertambahnya keterampilan peserta dalam proses pengecatan.

Instrumen evaluasi terdiri dari:

1) Daftar presensi sasaran.

2) Angket sasaran tentang pelaksanaan pelatihan dan produk (jobsheet) yang dihasilkan.

3) Jobsheet dilengkapi indikator keberhasilan.

\section{HASIL DAN PEMBAHASAN}

Jenis Luaran yang dihasilkan pada kegiatan PKM ini adalah berupa pelatihan yang berupa pelatihan bercocok tanam dengan menggunakan metode Hidroponik dengan menggunakan Wick System. Kegiatan pelatihan ini dilaksanakan di Kelurahan Gayungan RT 4/ RW 6, Surabaya. Juml;ah peserta yang hadir dalam kegiatan tersebut berjumlah 20 orang yang terdiri dari pensiunan PNS.

\section{Proses Pelaksanaan Pelatihan}

Pelaksanaan pelatihan dilaksanakan pada tanggal 14 Oktober 2017 bertempat di kelurahan Kelurahan Gayungan RT 4/ RW 6. Proses Pertama dalam pelaksanaan pelatihan adalah menyiapkan alat dan bahan untuk pelatihan penanaman hidroponik. Seperti yang ditunjukkan pada gambar 1 .

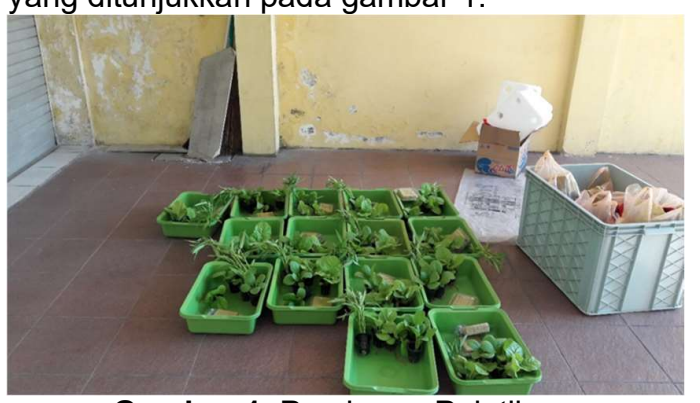

Gambar 1. Persiapan Pelatihan
Proses selanjutnya adalah pelatihan kegiatan bercocok tanam. Pada proses pelatihan ini dilaksanakan dengan cara berkoordinasi dengan tim PKM dan alumni mahasiswa UNESA yang berkecimpung di bidang hidroponik. Proses pelatihan dan penanaman dengan media hidropnik ditunjukkan pada gambar 2 dan gambar 3 .
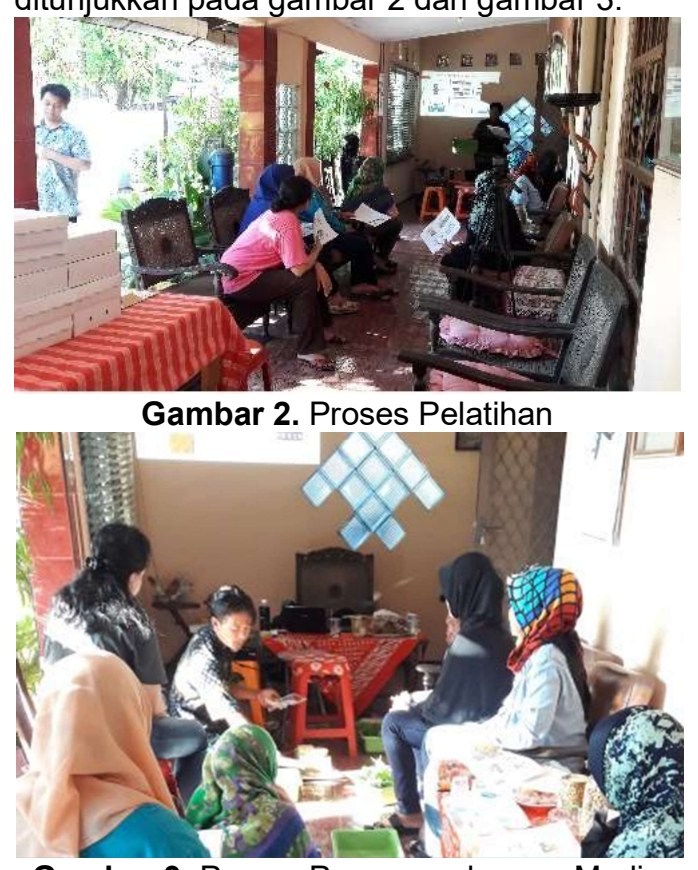

Gambar 3. Proses Penaman dengan Media Hidroponik

2. Proses Pemantauan dan Pendampingan

proses terakhir yang dilakukan adalah proses pendampingan. Pada proses ini, dilakukan pemantauan terhadap peserta selama proses penanaman. Berdasarkan hasil wawancara dengan mitra PKM, kesulitan yang dihadapi adalah menentukan jumlah takaran ideal untuk pemberian nutrisi. Nutrisi tersebut dapat mempengaruhi kadar $\mathrm{Ph}$ air yang berperan dalam memberikan kesuburan pada tanaman. Solusi yang diberikan adalah mengukur kadar $\mathrm{Ph}$ dengan menggunakan kertas lakmus atau $\mathrm{Ph}$ meter.

Analisa hasil respon peserta pelatihan bercocok tanam dengan menggunakan hidroponik di tunjukkan pada tabel 1 . Berdasarkan tabel tersebut didapatkan bahwa mayoritas peserta merasa puas dengan adanya pelatihan tersebut. Kepusan peserta paling tinggi berkaitan dengan kejelasan materi dan fasilitas ruangan pelatihan. Hampir seluruh peserta memberikan skor kepuasan antara tiga dan empat. Hal ini mengindikasikan bahwa pelatihan 
Tabel 1. Respon Peserta Pelatihan Bercocok Tanam dengan Menggunakan Hidroponik

\begin{tabular}{clcccc}
\hline \multirow{2}{*}{ No. Aspek yang dinilai } & \multicolumn{4}{c}{ Skor Kepuasan (\%) } \\
\cline { 3 - 6 } & & $\mathbf{4}$ & $\mathbf{3}$ & $\mathbf{2}$ & $\mathbf{1}$ \\
\hline 1 & Materi dijelaskan secara terorganisasi & 60 & 40 & 0 & 0 \\
\hline 2 & Kejelasan penyajian materi saat pelatihan & 50 & 50 & 0 & 0 \\
\hline 3 & $\begin{array}{l}\text { Pemateri sangat memahami materi yang } \\
\text { dipresentasikan }\end{array}$ & 55 & 45 & 0 & 0 \\
\hline 4 & Alokasi waktu diskusi & 52 & 48 & 0 & 0 \\
\hline 5 & $\begin{array}{l}\text { Kesempatan peserta untuk aktif bertanya dan } \\
\text { berpendapat }\end{array}$ & 45 & 55 & 0 & 0 \\
\hline 6 & $\begin{array}{l}\text { Pemateri memberikan jawaban pertanyaan secara } \\
\text { jelas }\end{array}$ & 50 & 42 & 8 & 0 \\
\hline 7 & Fasilitas ruang pelatihan & 60 & 40 & 0 & 0 \\
\hline 8 & Konsumsi yang diberikan & 55 & 45 & 0 & 0 \\
\hline 9 & Perangkat audio visual untuk pelatihan & 44 & 56 & 0 & 0 \\
\hline
\end{tabular}

\section{SIMPULAN DAN SARAN}

Berdasarkan hasil PkM yang telah dilaksanakan, Kesimpulan yang dapat diambil adalah sebagai berikut:

\section{Simpulan}

- Kegiatan pelatihan bercocok tanam dengan media hidroponik telah dilaksanakan di Kecamatan Gayungan RT 4/ RW 6.

- Kegiatan pelatihan diawali dengan penjelasan teknik menanam dan diakhiri dengan praktek penyemaian benih.

- Kesulitan yang dihadapi warga adalah menentukan komposisi nutrisi yang tepat sehingga berpengaruh terhadap nilai $\mathrm{Ph}$ air yang bermanfaat bagi akar untuk mengambil nutrisi.

\section{Saran}

Pada kegiatan selanjutnya diharapkan dilakukan pelatihan penanaman media hidroponik dengan sistem yang lebih maju, seperti water culture.

\section{DAFTAR PUSTAKA}

Lingga, Pinus. 2007. Hidroponik, Bercocok Tanam Tanpa Tanah. Penebar Swadaya Jakarta

Haryono, dkk. 1999. Buku Panduan Materi Kuliah Kewirausahaan. Unipres UNESA Surabaya.

Sutiono. 2002. Produktivitas UKM di Jawa Timur. Makalah yang disampaikan dalam rangka pelatihan produktivitas usaha kecil di Unesa,Tanggal 26 Juni tahun 2002. 